\title{
Aplicação da metodologia Design Science Research na indústria do carnaval: a gestão dos métodos e processos de criação coletiva na fábrica do carnaval sob a ótica do design \\ Application of the methodology Design Science Research in the Carnival Industry: The management of the methods and processes of collective creation in the carnival factory from the design perspective
}

Marcos Aurélio Machado, Eliana de Lemos Formiga \& Paulo de Oliveira Reis Filho

criação coletiva, carnaval, design science research, gestão, cadeia produtiva, cidade do samba

O presente trabalho busca compreender como se dá o processo de criação coletiva da fábrica do carnaval sob a ótica do Design. Visa também identificar e mapear os saberes tácitos envolvidos nestes processos e estudar as formas de como transformá-los em conhecimento explícito. Desta forma foi aplicada a gestão do conhecimento aliada à metodologia Design Science Research com foco na estratégia de estudo de caso na Cidade do Samba. Como resultado, foi desenvolvido um "Artefato" como um modelode fluxograma da cadeia criativa/produtiva da fábrica do carnaval.

collective creation, carnival, design science research, management, productive chain, cidade do samba

This study intends to understand how the process of collective creation of (Brazilian) carnival factory happens from the Design perspective. It also intends to identify and map the unspoken knowledge involved in these processes, and study the ways to turn them into explicit knowledge. Taking it into consideration, knowledge management was applied along with Design Science Research methodology, focusing on the strategy of case study at Cidade do Samba (Samba City). As a result, an "Artifact" was developed as a flowchart model of the creative/productive chain of carnival factory.

\section{Introdução}

Ao nos aproximarmos do universo alegórico do "maior espetáculo da terra", o carnaval carioca, pudemos cruzar a fronteira onde a realidade constrói a fantasia e, como expectadores privilegiados vivenciarmos os bastidores desta festa de sons, formas, texturas e cores.

Distintos estudos já abordaram o tema, porém, ao realizarmos uma revisão da literatura, percebemos que poucos autores se aprofundaram em questões mais específicas no campo do desenvolvimento projetual/estético desse espetáculo.

Entender as evoluções que ocorrem no barracão das escolas a partir do olhar do carnavalesco e do ofício da equipe de artistas e artesãos das escolas de samba foi a oportunidade para analisarmos como se estruturam os processos na cadeia de produção dos desfiles e de que forma este espaço de criação coletiva transformou-se na "Fábrica do Carnaval Carioca".

\section{Delimitação do tema}

Em entrevista dada para esta pesquisa, o estudioso do carnaval Milton Cunha (2017), comentou sobre a evolução técnica das escolas de samba:

Anais do 9 CIDI e 9 CONGIC

Luciane Maria Fadel, Carla Spinillo, Anderson Horta, Cristina Portugal (orgs.)

Sociedade Brasileira de Design da Informação - SBDI Belo Horizonte | Brasil | 2019

ISBN 978-85-212-1728-2
Proceedings of the 9th CIDI and 9th CONGIC

Luciane Maria Fadel, Carla Spinillo, Anderson Horta,

Cristina Portugal (orgs.)

Sociedade Brasileira de Design da Informação - SBDI

Belo Horizonte | Brazil | 2019

ISBN 978-85-212-1728-2 
Machado, M. A., Formiga, E. L., \& Reis Filho, P. O. | Aplicação da metodologia Design Science Research na indústria do carnaval: a gestão dos métodos e processos de criação coletiva na fábrica do carnaval sob a

As escolas não são espaços descolados da sociedade, estão plenamente inseridas nela através de seus componentes, de forma que quando a sociedade se transforma, as escolas se adaptam a estas transformações, que são traduzidas através dos seus desfiles.

A partir desta reflexão, é possível perceber que estas transformações chegariam até aos barracões das escolas em algum momento, de acordo com a visão compartilhada em seguida: "A era romântica ficou para trás. Os barracões das escolas de samba funcionam hoje como linhas de produção de uma moderna fábrica". Em sua afirmação, Prestes Filho (2009) sintetiza uma realidade atual, que se impõe à gestão das escolas do grupo especial:

\begin{abstract}
"Softwares sofisticados garantem carros alegóricos com estruturas mais leves e resistentes. $\mathrm{O}$ computador controla os efeitos luminosos que encantam o público no sambódromo. Os carnavalescos descobrem novos materiais para confecção de fantasias, alegorias e adereços. Não há mais espaço para amadorismo ou improvisações. Eficiência e eficácia, rentabilidade e adequação, receitas e custos, controle e qualidade são os atributos que agora devem prevalecer, para atender ao deslumbramento frequente de turistas estrangeiros e brasileiros que assistem aos desfiles, aos interesses públicos da prefeitura com a arrecadação de impostos e taxas, aos interesses privados das indústrias e dos prestadores de serviços com a lucratividade dos produtos vendidos e serviços prestados, e aos interesses institucionais das escolas de samba, que devem preservar e resguardar a euforia dos aficionados figurantes dos desfiles, a tradição da agremiação e a glória da instituição." (Prestes Filho, 2009, p.28)
\end{abstract}

Esta percepção compartilhada pelo autor ressalta a relevância dos processos de gestão nas escolas de samba, que podem ser comparadas com o modelo organizacional de uma grande empresa. Os métodos e processos de gestão nos barracões podem ser considerados como instrumentos de apoio aos que trabalham com a abordagem e resolução de problemas próprios do design: a valorização do projeto, do conceito e da estética. Em outras palavras, trata-se da inserção da cultura do design nos mais variados setores da sociedade.

\title{
A Cidade do Samba
}

Figura 1 - Vista aérea Cidade do Samba - Foto: www.skyscrapercity.com

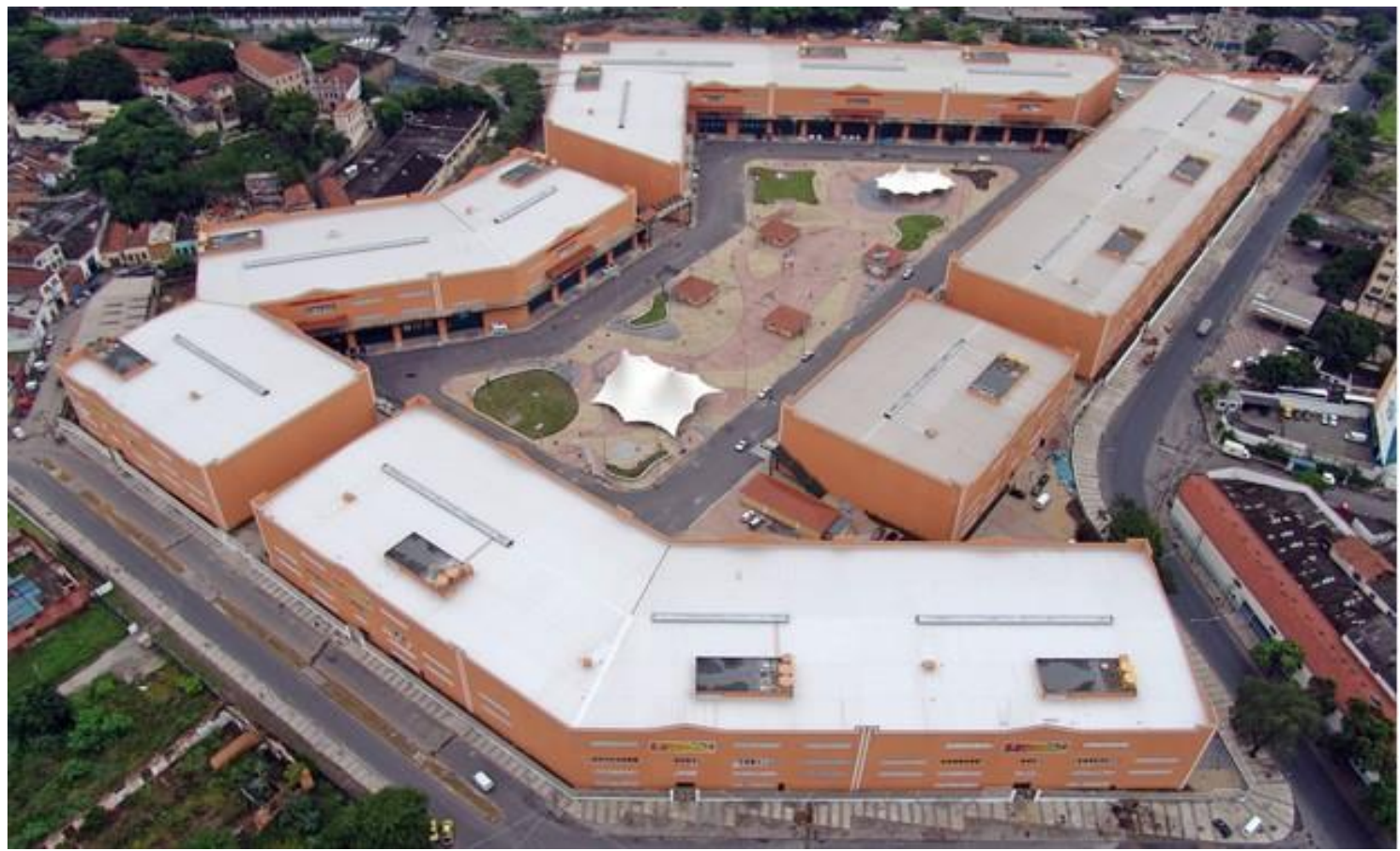


Machado, M. A., Formiga, E. L., \& Reis Filho, P. O. | Aplicação da metodologia Design Science Research na indústria do carnaval: a gestão dos métodos e processos de criação coletiva na fábrica do carnaval sob a

A Cidade do Samba é um espaço inteiramente dedicado à produção do carnaval carioca. Situada numa área de $92 \mathrm{mil}^{2}$ - equivalente a dez campos oficiais de futebol - 0 empreendimento envolveu investimentos superiores a $R \$ 100$ milhões, aplicados pela Prefeitura do Rio de Janeiro e reúne 14 galpões (cada um deles com um prédio de três pavimentos), um prédio administrativo, uma praça central equipada com duas lonas - uma para espetáculos, cobrindo uma área de $2.550 \mathrm{~m}^{2} \mathrm{e}$ outra para exposições, quatro lanchonetes com cinco banheiros, dois módulos sanitários públicos e 186 vagas de estacionamento. Os galpões são chamados pelos órgãos oficiais de "Fábricas do Carnaval" pelo seu grandioso porte e sofisticada infraestrutura.

\section{A Fábrica do carnaval}

Figura 2- Fachada dos galpões da Cidade do Samba. Foto: Marcos Machado.

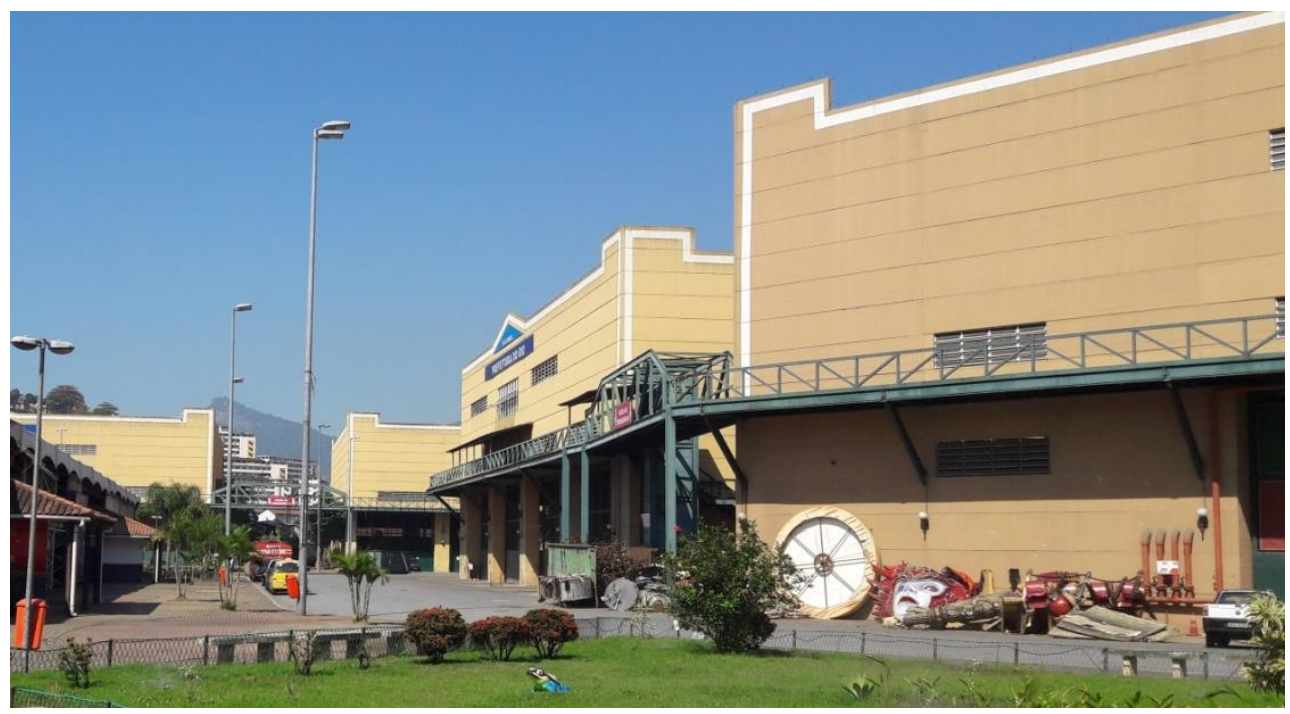

As "Fábricas do Carnaval", nome dado pela Liga para substituir os antigos barracões das escolas, consiste em um prédio de 03 andares especialmente projetado para atender às necessidades de criação e produção das agremiações. Apesar de todos os prédios serem estruturalmente iguais, é possível fazer adaptações nos espaços internos de cada pavimento de acordo com as necessidades específicas de cada escola.

Através dos croquis da fachada e do corte lateral do prédio (llustração 1), pode-se perceber algumas características importantes como os grandes galpões no pavimento térreo que são ideais para a produção dos imponentes carros alegóricos; espaços para os guindastes com trilhos para transporte de peças maiores e o vão de comunicação direta com o 3 o pavimento, que facilita o trabalho e transporte de grandes alegorias e esculturas. 
Machado, M. A., Formiga, E. L., \& Reis Filho, P. O. | Aplicação da metodologia Design Science Research na indústria do carnaval: a gestão dos métodos e processos de criação coletiva na fábrica do carnaval sob a ótica do design

llustração 1 - Esquemas da fachada e corte lateral Fábrica do Carnaval - do autor
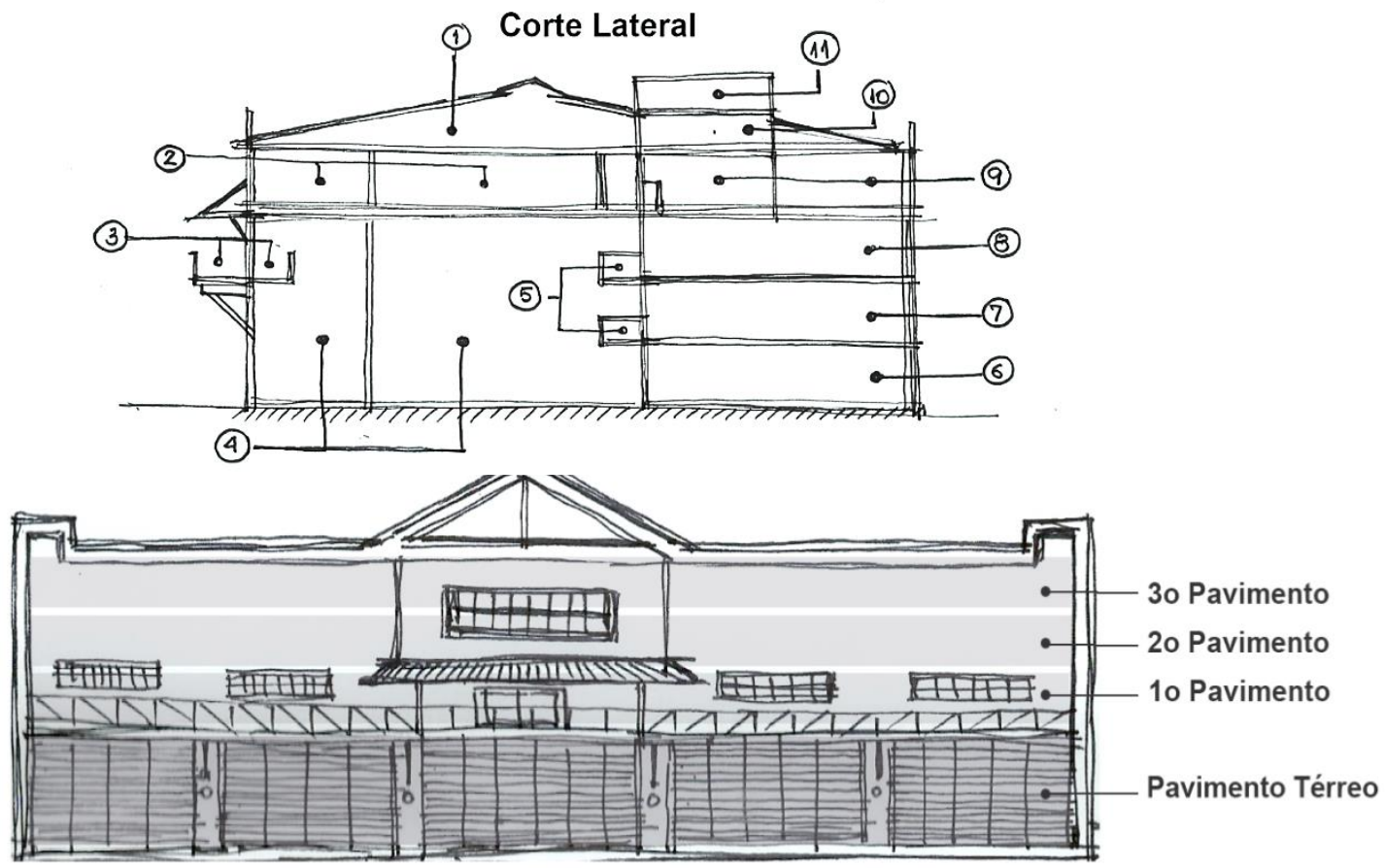

1 - Telhado

2 - $3^{\circ}$ pavimento / Ateliês e Oficinas

3 - Sacadas externa e interna (visitantes)

4 - Galpões de Carros Alegóricos

5 - Balcões internos

6 - Pavimento térreo / Almoxarifado e Oficina
7 - 1 Pavimento / Refeitório e Oficinas

$8-2^{\circ}$ Pavimento / Deptos. Administrativos e Imprensa

9 - 3ํㅗaimento / Ateliês, Oficinas e Almoxarifado

m 10 - Caixa de Máquinas / Elevadores

a 11 - Caixa d'Água

\section{Problema da pesquisa}

Como a gestão do design pode contribuir para o mapeamento da cadeia criativa e produtiva na fábrica do carnaval, e a partir da análise de seus métodos e processos transformar o conhecimento tácito em conhecimento explícito. 
Machado, M. A., Formiga, E. L., \& Reis Filho, P. O. | Aplicação da metodologia Design Science Research na indústria do carnaval: a gestão dos métodos e processos de criação coletiva na fábrica do carnaval sob a

\section{Gestão do conhecimento: o ciclo Nonaka e Takeuchi}

Gráfico 1 - O Ciclo Nonaka e Takeuchi

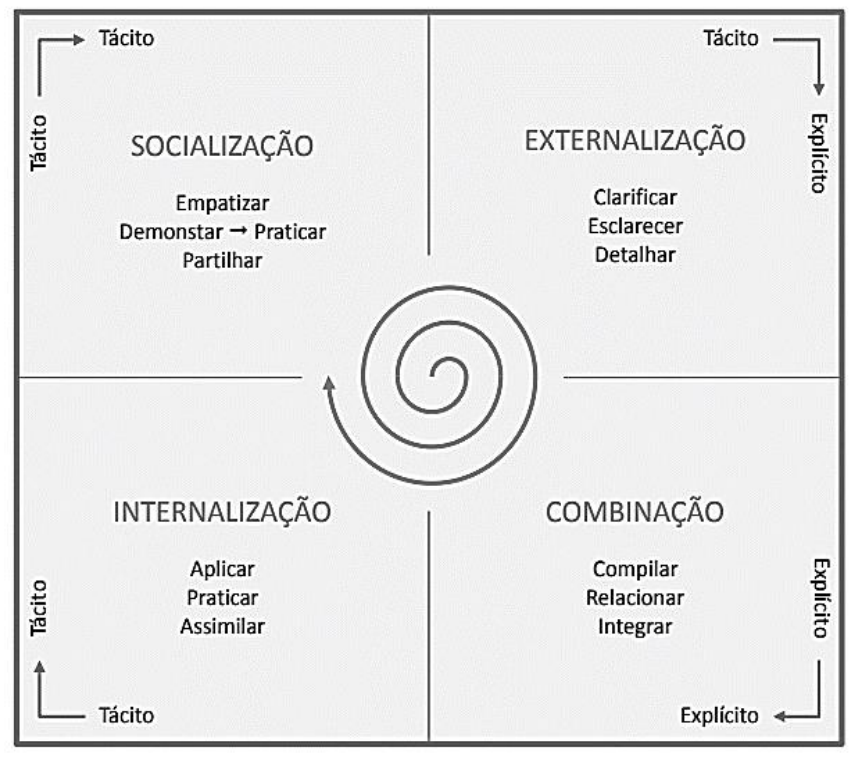

Entender como se organiza e se dissemina o conhecimento gerado a partir dos dados da pesquisa foi um dos primeiros aspectos deste estudo.

Nonaka e Takeuchi, acadêmicos japoneses que, a partir de 1995, propuseram um modelo explicativo sobre a forma como o conhecimento é criado, disseminado, enriquecido e incorporado aos processos, às rotinas e à própria cultura das organizações.

A gestão do conhecimento é hoje um processo organizacional de importância fundamental, que consiste em identificar, localizar, disseminar, recombinar e aplicar o conhecimento a que a organização tem acesso a partir, quer do seu interior quer do exterior das suas fronteiras orgânicas, com o objetivo de otimizar aquele triplo objetivo de competitividade, inovação e criação de valor. Segundo Nonaka e Takeuchi, o conhecimento se dá por 02 formas:

\section{- Conhecimento Tácito}

É o tipo de conhecimento que detido pelos indivíduos e difícil de codificar em suportes exteriores a estes, é específico de determinados contextos e feito de experiências pessoais. Como exemplos, é possível citar: o gesto do artesão ou do desportista, o "toque" do artista, a receita do cozinheiro, por exemplo.

\section{- Conhecimento Explícito}

É o conhecimento registrado e codificado em qualquer suporte exterior às pessoas e expresso em palavras, números, fórmulas, grafismos, ou qualquer outro código. São exemplos: receitas, desenhos, mapas, gráficos, patentes, descrições de processos, regras e procedimentos, por exemplo. 
Machado, M. A., Formiga, E. L., \& Reis Filho, P. O. | Aplicação da metodologia Design Science Research na indústria do carnaval: a gestão dos métodos e processos de criação coletiva na fábrica do carnaval sob a

O gráfico abaixo detalha as etapas, processos e os produtos na gestão proposta por Nonaka e Takeuchi, e que foi aplicada a esta pesquisa:

Tabela 2 - O Ciclo Nonaka e Takeuchi

\begin{tabular}{|c|c|c|}
\hline ETAPA & PROCESSO & PRODUTOS \\
\hline SOCIALIZAÇÃO & $\begin{array}{l}\text { O conhecimento tácito é transmitido de } \\
\text { pessoa a pessoa; esta transmissão é } \\
\text { experiencial, ativa, e envolve a uma interação } \\
\text { direta entre as pessoas envolvidas, que } \\
\text { implica a partilha de experiências e modelos } \\
\text { mentais. Este processo é exemplificado pela } \\
\text { relação entre mestre e aprendiz. }\end{array}$ & $\begin{array}{l}\text { Experiência partilhada. } \\
\text { Competências e know- } \\
\text { how dos indivíduos. } \\
\text { Confiança mútua, } \\
\text { empatia. } \\
\text { Preocupação com a } \\
\text { perfeição. }\end{array}$ \\
\hline EXTERNALIZAÇÃ̃O & $\begin{array}{l}\text { O conhecimento tácito é transformado em } \\
\text { conhecimento explícito, através da sua } \\
\text { captura e codificação numa forma facilmente } \\
\text { inteligivel por aqueles que não estão } \\
\text { familiarizados com ele (eg. descrição escrita). } \\
\text { Este processo envolve habitualmente um } \\
\text { diálogo com os detentores do conhecimento } \\
\text { implícito, pois estes conseguem articular as } \\
\text { suas ideias com maior clareza quando são } \\
\text { confrontados com questões e feedback por } \\
\text { parte do interlocutor. A externalização } \\
\text { desenvolve-se do individuo para o grupo. }\end{array}$ & $\begin{array}{l}\text { Conhecimento explícito } \\
\text { articulado em imagens, } \\
\text { simbolos e linguagem. } \\
\text { Procedimentos escritos. } \\
\text { Desenhos. } \\
\text { Planos. } \\
\text { Instruções. } \\
\text { Receitas. }\end{array}$ \\
\hline COMBINAÇÃO & $\begin{array}{l}\text { Vários elementos de conhecimento explícito } \\
\text { são associados e combinados num todo } \\
\text { coerente. Este processo implica a consulta de } \\
\text { elementos de conhecimento explícito e a } \\
\text { edição das suas descrições num único } \\
\text { documento. Esta dinâmica desenvolve-se de } \\
\text { um grupo para outros grupos. }\end{array}$ & $\begin{array}{l}\text { Processos. } \\
\text { Protótipos. } \\
\text { Sistemas. } \\
\text { Manuais. } \\
\text { Políticas. } \\
\text { Estratégias. }\end{array}$ \\
\hline INTERNALIZAÇÃO & $\begin{array}{l}\text { O conhecimento explicito é absorvido, } \\
\text { interpretado e integrado com o restante } \\
\text { conhecimento do individuo, transformando- } \\
\text { se em conhecimento tácito detido por este. } \\
\text { Esta dinâmica é experiencial, através da } \\
\text { aplicação dos conceitos e dos métodos } \\
\text { prescritos (na realidade ou por meio de } \\
\text { simulações) e da perceção dos respeitivos } \\
\text { limites e condições de aplicabilidade. }\end{array}$ & $\begin{array}{l}\text { Experiência individual. } \\
\text { Condições de aplicação } \\
\text { (sucesso / insucesso). } \\
\text { Hábitos e rotinas. } \\
\text { Cultura. }\end{array}$ \\
\hline
\end{tabular}

\section{A metodologia Design Science Research}

A partir da definição da gestão do conhecimento, foi necessário identificar a metodologia a ser aplicada a este perfil de pesquisa. Estudos conduzidos nesta área, têm como referência os objetivos e as práticas das pesquisas realizadas sob o paradigma das ciências naturais e sociais. Tanto as pesquisas sustentadas nas ciências sociais quanto aquelas alicerçadas nas 
Machado, M. A., Formiga, E. L., \& Reis Filho, P. O. | Aplicação da metodologia Design Science Research na indústria do carnaval: a gestão dos métodos e processos de criação coletiva na fábrica do carnaval sob a

ciências naturais têm como missão a busca pela verdade, sendo seus objetivos descrever, explicar e predizer, com o intuito de desenvolver o conhecimento em determinada área (Denyer, et al., 2008). Pesquisadores da área de gestão, em geral, buscam encontrar soluções para certos problemas, ou ainda, projetar e criar artefatos que sejam aplicáveis por profissionais no dia a dia. Desta forma, um estudo que apenas descreva ou explique uma determinada situação nem sempre é suficiente para o avanço do conhecimento (Dresch et al., 2015).

A partir desta análise, pode-se perceber a importância na escolha de uma metodologia que mais se adequasse aos objetivos da pesquisa. Quando se propôs um olhar sobre a gestão do design aplicado aos desfiles das escolas de samba as palavras "gestão" e "design" foram norteadoras para a escolha e utilização da metodologia Design Science Reseach (DSR).

\section{O surgimento e a evolução da Design Science}

Em função da escolha da metodologia, cabe aqui desenvolver um breve histórico sobre as suas origens. O recorte do texto do livro Design Science Research (Dresch et al, 2015), esclarece:

A expressão Science of design, que posteriormente passou a ser design Science, foi introduzida pela obra "As ciências do artificial", do economista e psicólogo norte-americano Herbert Alexander Simon (1996). Em português, encontramos diferentes traduções da expressão: "ciência do artificial", "ciência do projeto" e até "ciência da engenharia". Aqui, será usado simplesmente Design Science. Em sua obra seminal, Simon diferencia o que é natural do que é artificial. Artificial, segundo ele, é algo que foi produzido ou inventado pelo homem ou que sofre intervenção deste. Como exemplo de artificial, ele cita as máquinas, as organizações, a economia e até mesmo a sociedade.

Para Simon (1996), as ciências do artificial devem se preocupar com a maneira como as coisas devem ser para alcançar determinados objetivos, seja para solucionar um problema conhecido ou para projetar algo que ainda não existe. Projetar, aliás, é uma função característica das ciências do artificial.

Fazendo uma pontuação breve, a partir de March e Smith (1995, p.256), a lógica do método Design Science Research busca o desenvolvimento e a avaliação de 'constructos, modelos, métodos e instanciações', os quais dialogam, permanentemente, com o foco e a 'intenção do projeto'. Ralph e Wand (2009, p.104) colocam esta abordagem, em diálogo com a lógica da Design Science, que, como querem Freeman e Hart (2004), se conforma como um paradigma de pesquisa semelhante ao experimentalismo. Assim, as duas abordagens mescladas, poderiam ser vistas como um processo conduzido pelo rigor científico, baseado nas metas evolutivas de conformação de constructos ${ }^{1}$, que se constituem com o auxílio de uma série de métodos complementares e que se permite comportar de forma interativa e retro alimentável.

Este campo de pesquisa se fundamenta na experimentação e, assim, tem por objetivo expandir as fronteiras em todos os ramos de conhecimento, numa atitude de explorar novos conceitos e representações de um mundo em constante transformação - traz, assim, implícito, o potencial de ruptura com os paradigmas e normas estabelecidas. Fidalgo e Moura (2014) avançam no conceito ao abordar as dinâmicas que compõem esta experiência:

Aprendemos a viver e a conviver, desde o nascimento, em tal ambiente e essa vivência e convivência tornam objetos concebidos pela mão do homem em algo que parece ser natural. O designer é capaz de "antecipar mundos", criar objetos que modificam nossa percepção e projetar um significativo impacto cultural, "enquanto forma de construção - ou construção da forma - de identidades individuais e sociais" (Fidalgo e Moura, 2014, p.11).

\section{A estrutura para a condução da pesquisa}

A metodologia Design Research é, sem dúvida, uma abordagem que pode orientar pesquisas que se destinam a projetar ou desenvolver algo novo, uma vez que a Design Science tem como foco causar a mudança, criando artefatos ${ }^{2}$ e gerando soluções para problemas

\footnotetext{
${ }^{1}$ Modelo criado mentalmente que, elaborado com base em dados simples e partindo de ações analisáveis, é usado por especialistas para compreender uma parte específica de uma teoria.
} 
Machado, M. A., Formiga, E. L., \& Reis Filho, P. O. | Aplicação da metodologia Design Science Research na indústria do carnaval: a gestão dos métodos e processos de criação coletiva na fábrica do carnaval sob a

existentes. A proposição deste método não exclui como úteis os demais métodos de pesquisa. Ao contrário, o objetivo é justamente ampliar o portfólio de métodos disponíveis para as pesquisas em áreas como a gestão, por exemplo, evitando enquadramentos metodológicos inadequados ou impróprios para o objeto que se deseja estudar.

Através do gráfico X, pode-se entender melhor como a metodologia Design Science Research pode ser aplicada na solução de problemas no ambiente organizacional de forma que contribua para a base do conhecimento de uma maneira relevante e replicável.

\section{A pesquisa de campo}

Conforme visto anteriormente, o campo da pesquisa foi o ambiente interno do galpão da fábrica do carnaval. O pesquisador de campo se propôs à observação dos fatos e fenômenos exatamente como ocorrem no mundo real, através do registro, coleta, análise e interpretação dos dados e com base em uma fundamentação teórica consistente, tornando possível uma melhor compreensão e explicação do problema pesquisado.

Gráfico 3 - Características gerais da metodologia Design Science Research
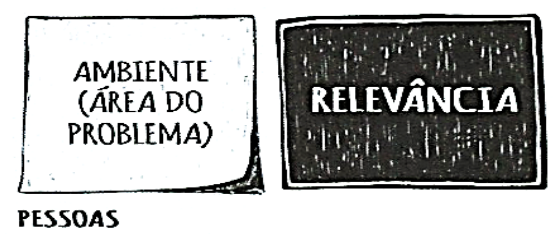

- PAPÉIS

- competências

- características

ORGANIZAÇŌES

- estrategias

- estrutura

- cultura

- pROCESSOS

TECNOLOGIA

- infraestrutura

- aplicaçōes

- arquitetura de

comunicações

- COMPETENNCIAS DE

DESENVOLVIMENTO

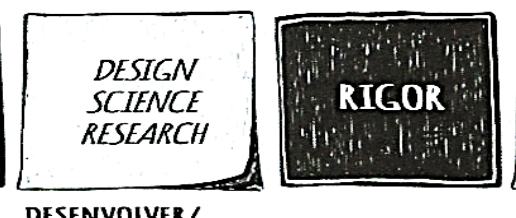

DESENVOLVER/

CONSTRUIR

- teorias

- aRTEFAtOS

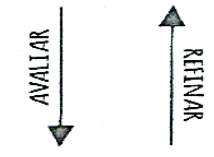

JUSTIFICAR/

AVALIAR (FORMAS)

- analítica

- estudo de caso

- exPERIMENTAL

- estudo de CAMPO

- SIMULAÇĀO
BASE DE CONHECIMENTO

FUNDAMENTOS

- teorias

- FRAMEWORKS

- instRumentos

- constructos

- MODELOS

- MÉtodos

- instanciaçōes

METODOLOGIAS

- TÉCNICAS DE

ANÁLISE DE DADOS

- FORMALISMOS

- Medidas

- CRITÉRIOS DE

VAIIDAÇÃO

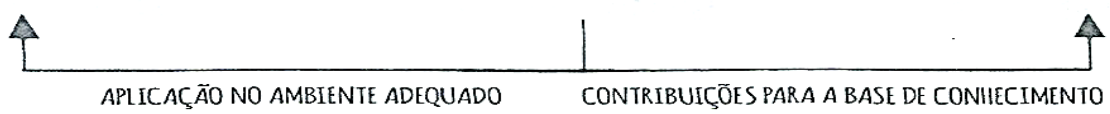

Dependendo da natureza do tema a ser pesquisado, a definição das técnicas de coleta e análise pode variar. Neste caso, a abordagem foi qualitativa e exploratória, de acordo com um certo ineditismo no recorte proposto ao campo desta pesquisa. O método de observação participante ou observação direta também foi utilizado em campo, que de acordo com Gil "as pesquisas exploratórias têm como principal finalidade desenvolver, esclarecer e modificar conceitos e ideias, tendo em vista a formulação de problemas mais precisos ou hipóteses pesquisáveis para estudos posteriores" (Gil,1999, p.43).

Outro aspecto relevante nesta pesquisa refere-se ao caderno ou diário de campo. Segundo Malinowski (1975), o diário de campo é uma das bases do método etnográfico. Outro aspecto que pode ser destacado, de acordo com o design da informação, consiste na utilização do 
Machado, M. A., Formiga, E. L., \& Reis Filho, P. O. | Aplicação da metodologia Design Science Research na indústria do carnaval: a gestão dos métodos e processos de criação coletiva na fábrica do carnaval sob a

desenho como uma ferramenta de representação gráfica das etapas envolvidas nas pesquisas. Através da imersão profunda e interação continuada, possibilita registros de todas as ordens, durante os processos de observação direta.

Utiliza-se de métodos variados para (d)escrever as práticas culturais observadas, como a coleta de dados, registros de áudio e vídeo, desenhos, croquis e quadros cinéticos.

llustração 2 - Exemplo de desenhos produzidos no caderno de campo do pesquisador. Marcos Machado (2017)

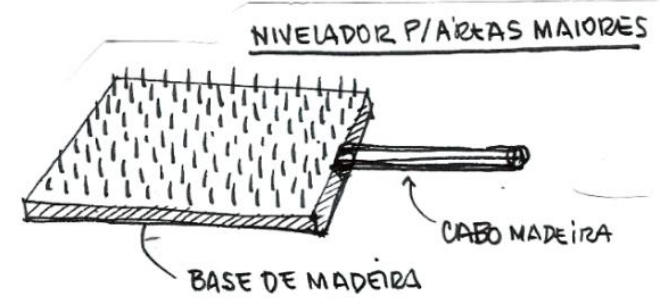

$$
\begin{aligned}
& \text { OES WULOR FAZ UM PLANEJAMENTO } \\
& \text { DAMONTAGEM DA ESCUUURA, OU SEJA; } \\
& \text { EM QUANTAS PARES SERA' DIVIDIDA. }
\end{aligned}
$$

AS PARTESLIXADAS E PLANAS

SÁ́ COLADAS COM UMA COLA DE POUURETAMO: DEDOIS DE SECAS

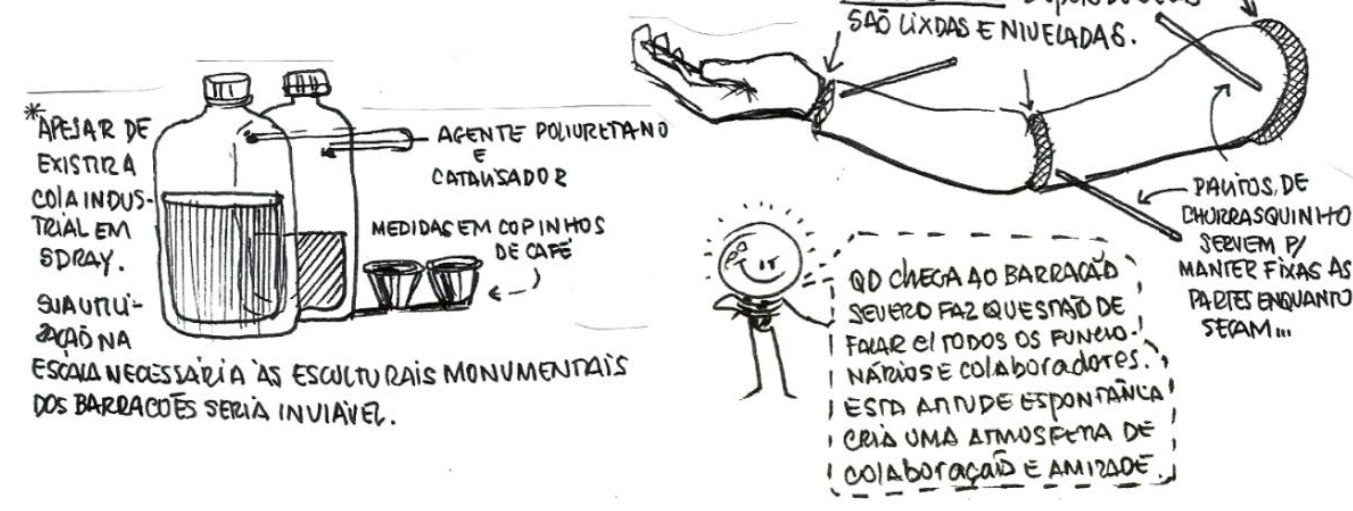

"Além de ser utilizado como instrumento reflexivo para o pesquisador, o gênero diário é, em geral, utilizado como forma de conhecer o vivido dos atores pesquisados, quando a problemática da pesquisa aponta para a apreensão dos significados que os atores sociais dão à situação vivida. $O$ diário é um dispositivo na investigação, pelo seu caráter subjetivo, intimista" (Macedo, 2010, p. 134).

\section{Características da metodologia aplicada ao campo}

A - O método de observação direta seria utilizado para o registro dos dados da pesquisa de campo. As visitas ficaram definidas para uma vez por semana, com liberdade de acesso a todos os departamentos, ateliês e oficinas.

B - O perfil exploratório da fase inicial do trabalho de pesquisa, consistiu em observar o campo, buscando entender a organização das equipes de trabalho e suas funções.

C - Em um segundo momento, a pesquisa pelos 04 andares do barracão, rendeu conversas informais com os responsáveis e colaboradores, e serviu para gerar uma presença mais amigável no espaço do trabalho.

D - Na chegada à Fábrica do Carnaval, a primeira parada sempre foi o departamento de criação, onde o carnavalesco e seu assistente de arte sempre atualizavam este pesquisador sobre 0 andamento dos trabalhos desde a semana anterior.

E - Após estar ambientado com a maioria dos que trabalham no barracão, este pesquisador sentiu-se à vontade para iniciar os registros dos processos em andamento. Para tal utilizou uma câmera digital para fotos e pequenos vídeos.

F - Através do conjunto de informações e dados preliminares coletados, foi possível elaborar um modelo de protocolo de pesquisa e um roteiro de entrevistas. 
Machado, M. A., Formiga, E. L., \& Reis Filho, P. O. | Aplicação da metodologia Design Science Research na indústria do carnaval: a gestão dos métodos e processos de criação coletiva na fábrica do carnaval sob a

G - As entrevistas feitas a partir dos protocolos de pesquisa serviram como principal fonte para o desenvolvimento do artefato da pesquisa: o mapeamento da cadeia criativa/produtiva na Fábrica do Carnaval.

H - A utilização do "diário de campo" foi fundamental pelas anotações e desenhos feitos de próprio punho sobre os métodos e processos de produção. Estes dados serviram como base para a construção mental (constructo) do que viria a ser o futuro artefato.

\section{0 projeto do artefato}

Após analisar a situação atual onde ocorre o problema e as possíveis soluções para alterar ou melhorar o cenário presente, foram delineadas as características internas e o contexto de atuação do artefato. Para que o projeto fosse bem desenvolvido, este teria que levar em consideração as questões formalizadas nas etapas anteriores (gráfico 3). Tais questões foram relevantes para o rigor da pesquisa, permitindo que o conhecimento construído fosse replicado e confirmado posteriormente por outros pesquisadores.

Gráfico 3 - Redesenho conforme fonte primária

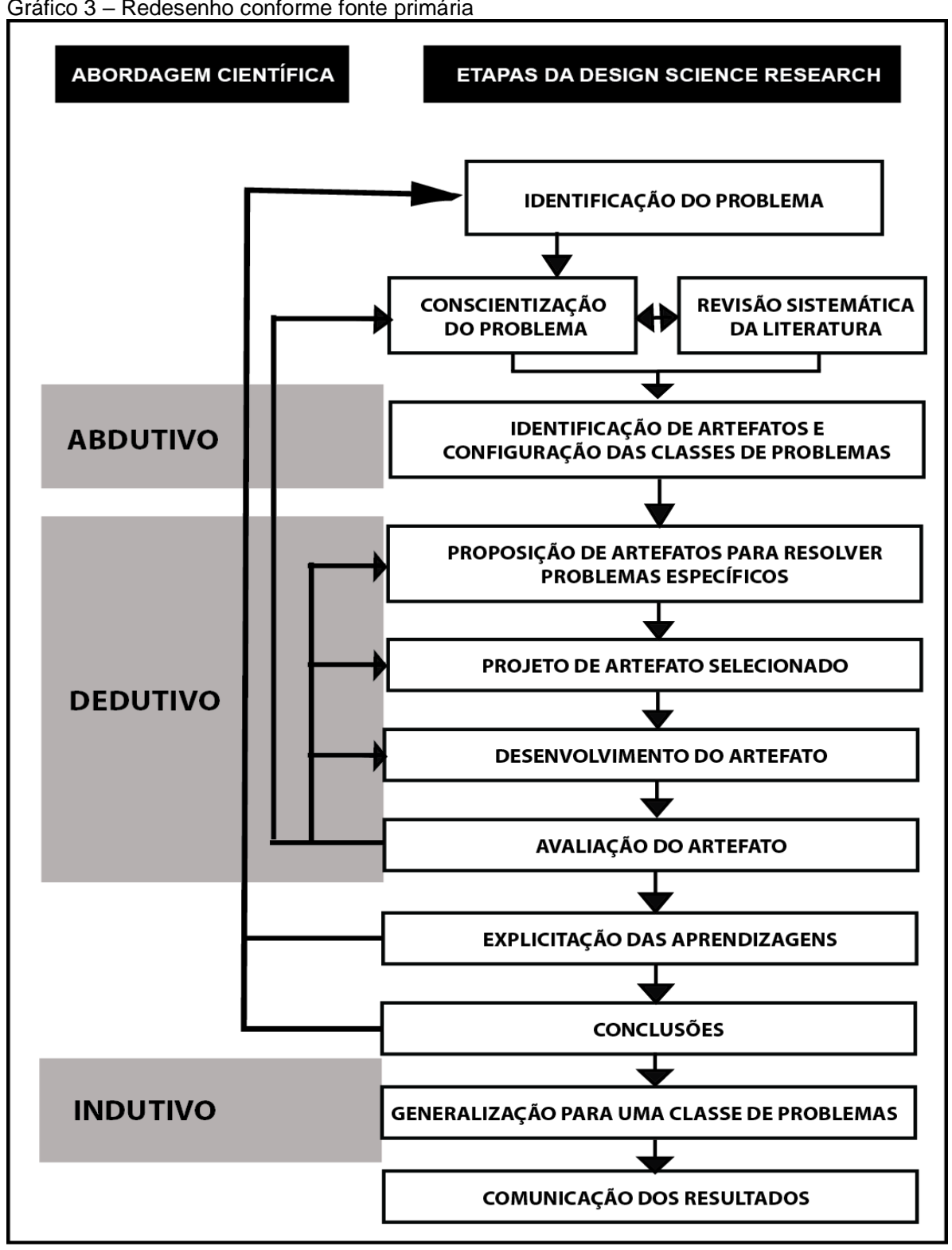


Machado, M. A., Formiga, E. L., \& Reis Filho, P. O. | Aplicação da metodologia Design Science Research na indústria do carnaval: a gestão dos métodos e processos de criação coletiva na fábrica do carnaval sob a

Para que fosse viável o mapeamento da cadeia produtiva na fábrica do carnaval, certos procedimentos foram necessários, entre eles entender o ciclo de etapas que compõem os desfiles das escolas do grupo especial do Rio de Janeiro. De acordo com Prestes Filho (2009), este processo é o início de um conjunto sequenciado de atividades que, organizado de forma linear, desenvolve-se etapa por etapa em uma cadeia até seu clímax, que serão doze horas de entretenimento ininterrupto que ocorrerão na Passarela do Samba. Para uma melhor percepção deste ciclo, segundo os princípios do design aplicado à informação, foi elaborado um gráfico no modelo linha do tempo, onde os principais elos desta cadeia estão identificados através de cores e setas que sugerem uma cronologia aproximada de eventos que devem ocorrer no prazo de 12 meses (gráfico 4).

Observando-se o gráfico 3, é possível verificar que a pesquisa em sua abordagem Abdutiva identificou a classe a que pertence o problema em questão e suas principais características. Desta forma, pode ser iniciada a etapa chamada Dedutiva, ou seja, desenvolver os processos mentais, conhecidos como "constructos", como base para a criação de um artefato que respondesse de forma satisfatória ao problema proposto.

Após a abordagem inicial de campo (Fábrica do Carnaval), foi desenvolvido um modelo de protocolo de pesquisa com foco na identificação dos principais elos da cadeia produtiva e suas características, através de entrevistas diretas com os principais atores participantes destes processos.

\section{Mapeamento gráfico da cadeia produtiva}

De acordo com Simon (1996), um artefato não precisa necessariamente ser algo físico, pode ser uma construção heurística de um conhecimento. Esta foi a opção escolhida para esta pesquisa, nesta etapa será construído o ambiente interno do artefato. As entrevistas revelaram que os departamentos, oficinas e ateliês envolvidos na produção do carnaval, operam de forma independente, recebendo orientações diretamente do carnavalesco ou dos responsáveis pelos setores. Uma importante questão identificada foi a não existência de qualquer modelo da cadeia de criação e produção dos desfiles para consulta, o que dificulta uma visualização macro dos métodos e processos envolvidos.

Ilustração 3- Constructo inicial do mapeamento da cadeia produtiva - do autor

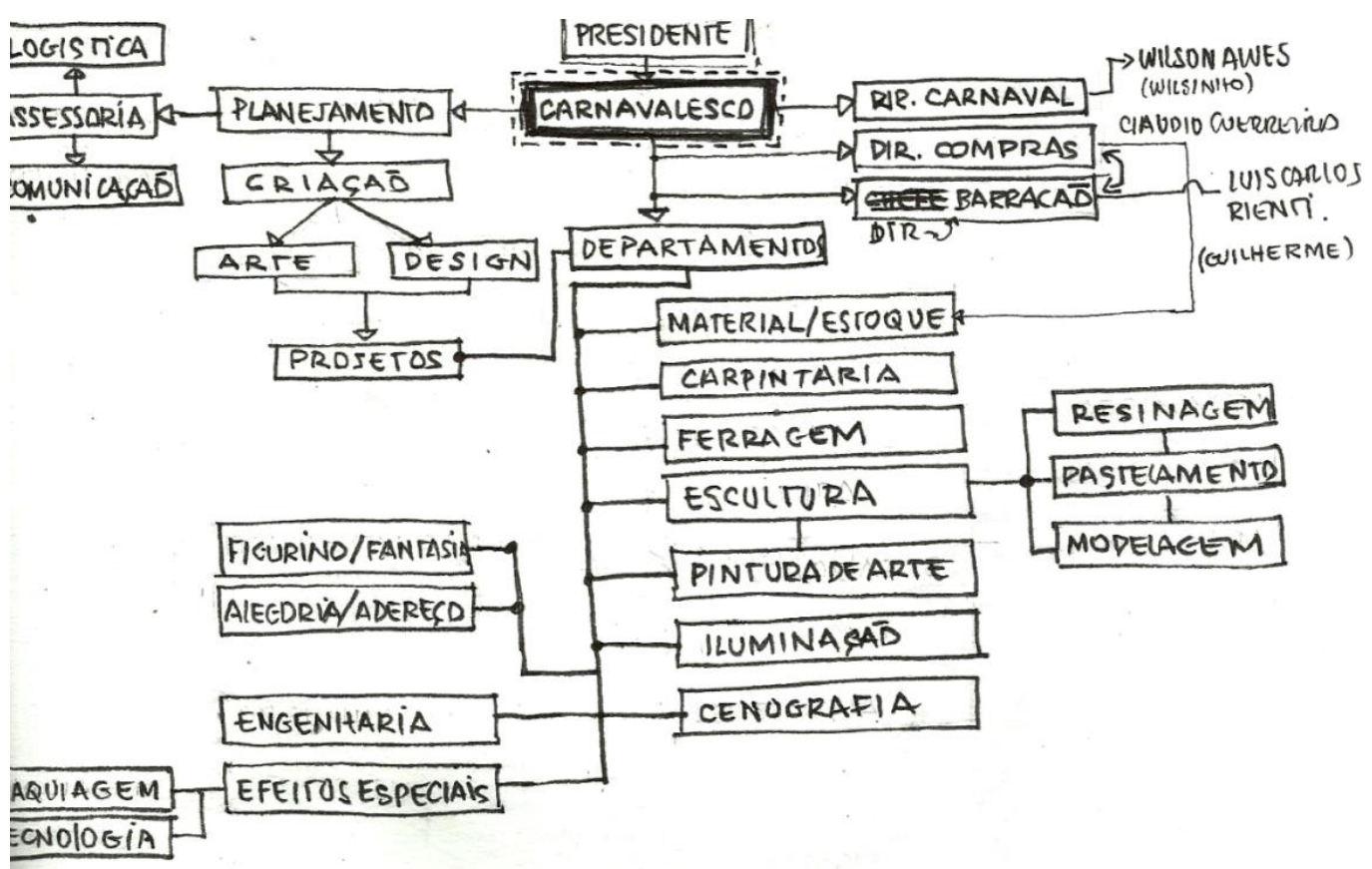

Anais do 9o Congresso Internacional de Design da Informação | CIDI 2019 
Machado, M. A., Formiga, E. L., \& Reis Filho, P. O. | Aplicação da metodologia Design Science Research na indústria do carnaval: a gestão dos métodos e processos de criação coletiva na fábrica do carnaval sob a

Esta lacuna encontrada norteou a construção interna do artefato, que se estruturou através do mapeamento das relações entre os setores da cadeia produtiva, com a divisão final em 05 grandes áreas: Gestão > Pré-Produção > Produção > Pós-Produção > Desprodução.

- Gestão: Centrado na figura do Carnavalesco, envolve a Presidência, a Diretoria de carnaval, a Diretoria de compras e a Diretoria de barracão. Estes departamentos concentram a gestão política, administrativa, financeira e operacional da fábrica do carnaval.

- Pré-produção: A criação é coordenada pelo carnavalesco, é considerado o principal departamento da cadeia criativa, pois todos os projetos dos desfiles nascem neste espaço.

- Produção: São as oficinas e ateliês onde os projetos tomam forma, cores e texturas. São as oficinas e ateliês de Ferragem; Carpintaria; Escultura; Laminação; Pintura e Fantasias.

- Pós-produção: Inclui atividades de finalização dos processos, como montagem de elementos cenotécnicos e efeitos especiais, assim como testes de engenharia e ergonomia em carros alegóricos.

- Desprodução: Esta etapa consiste em definir o destino final dos elementos alegóricos produzidos na fábrica do carnaval, que envolve reciclagem, reuso ou repasse.

\section{Desenvolvimento dos artefatos}

Após a conclusão do projeto, foi iniciada a etapa de desenvolvimento do artefato. Em sua construção foram utilizadas variadas abordagens que melhor se adequaram ao projeto. Nesta fase o pesquisador constrói o ambiente interno do artefato (Simon,1996). O Design Science Research pode ser utilizado tanto para a construção de algo físico, quanto para gerar conhecimento.

As características da pesquisa, por seu caráter de extremo dinamismo, necessitaram de permanente e eficaz processo de registro multimodal. O registro dos achados, bem como dos processos 'quali' que foram utilizados, foram explicitados, em diferentes plataformas cognitivas - para a abrangência da disseminação, a redundância das informações, nos ambientes complexos, deve ser visto como uma premissa operacional. O arranjo das informações, para melhor absorção e retenção, teve como objetivo organizar e apresentar os dados, agregando valor informacional, imprimindo sentido e oferecendo a estrutura cognitiva necessária para que estas pudessem, de forma efetiva, se expressar e disseminar conteúdos.

Dessa forma, os objetivos do constructo, com base em Horn (2000) são: o desenvolvimento de outputs informacionais compreensíveis, acessíveis e de ágil tradução; interface com o projeto que tenha caráter interativo e propositivo, com linguagem fácil e próxima do natural; objeto físico ou virtual - para uma orientação confortável, eficiente e eficaz.

Para que se possa facilitar o entendimento do processo de elaboração do artefato, serão divididos em 04 outputs:

\section{A - Constructos do caderno de campo}

Fonte primária de registros da pesquisa, a técnica de anotações gráficas em caderno de campo revelou-se uma ferramenta valiosa no desenvolvimento interno do artefato. O modelo pouco invasivo e altamente personalizado do traço e da anotação manual foram muito utilizadas na fábrica do carnaval, sendo um aliado importante no registro da informação e na construção do artefato.

No recorte abaixo é possível identificar alguns aspectos relevantes para o design da informação contidas no caderno de campo. 
Machado, M. A., Formiga, E. L., \& Reis Filho, P. O. | Aplicação da metodologia Design Science Research na indústria do carnaval: a gestão dos métodos e processos de criação coletiva na fábrica do carnaval sob a

Ilustração 4 - Desenhos e anotações feitas no caderno de campo - Marcos Machado (2017)

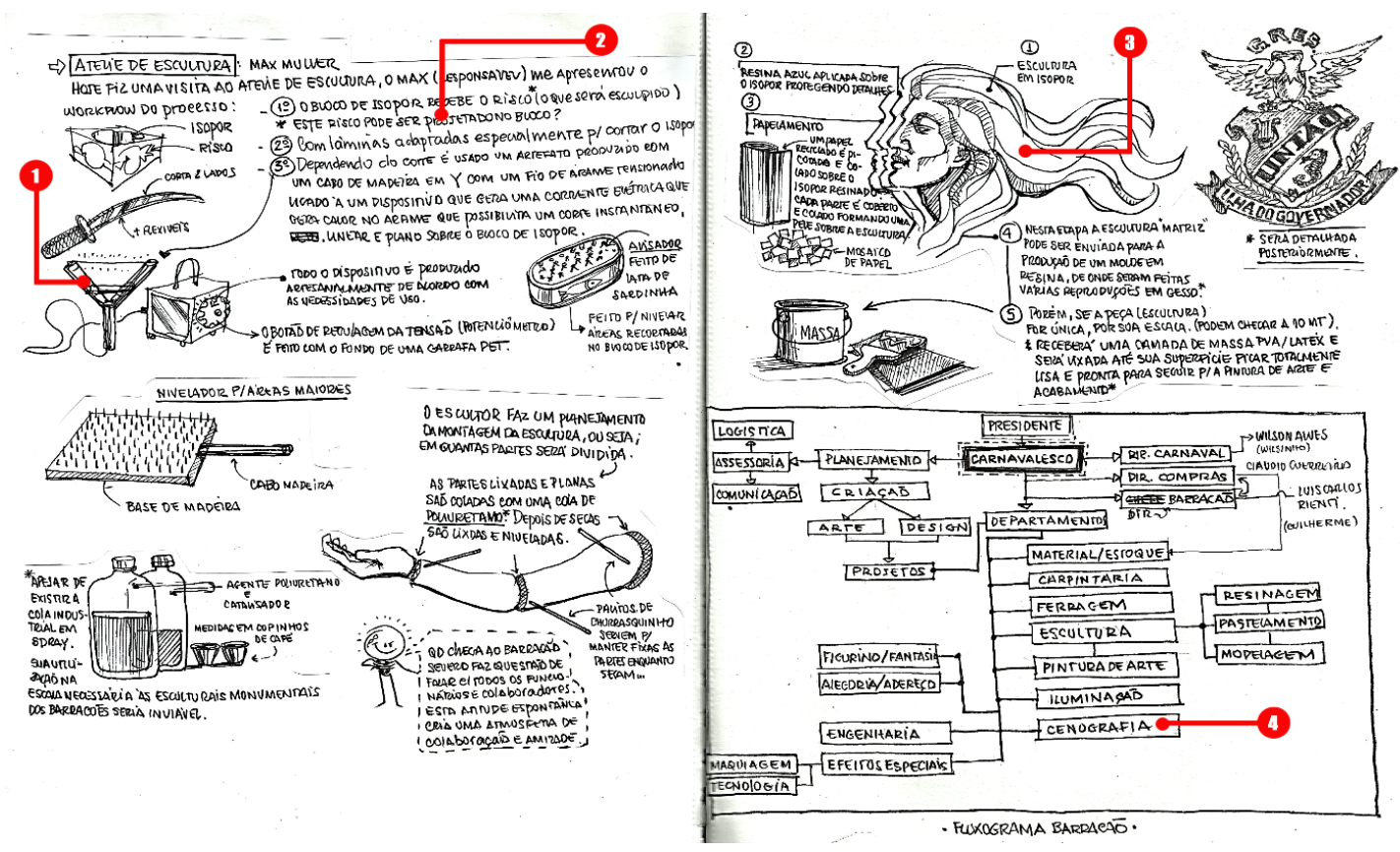

1- Exemplo de ferramentas criadas e produzidas pelos próprios artesãos para execução de tarefas, em uma clara aplicação do design espontâneo (vernacular) na solução de problemas próprios de seu ofício.

2- Anotações escritas no caderno de campo com o objetivo de explicitar um conhecimento específico.

3- Os croquis feitos à mão tiveram o objetivo de anotação visual das informações no momento em que foram explicitadas pelos artesãos no campo de pesquisa.

4- Esquema inicial na tentativa de elaborar a estrutura para o artefato da cadeia produtiva.

\section{B - Gráfico Linha do tempo}

De acordo com Brenda Dern, p.37, um dos aspectos inerentes ao design da informação é o de impor um senso de ordenação à uma realidade aparentemente caótica. Desta forma, o desenvolvimento de um gráfico no formato de linha do tempo possibilitou uma visualização geral dos eventos envolvidos durante o espaço de 12 meses na elaboração dos desfiles das escolas do grupo especial.

1- Barra central horizontal dividida em 12 partes, sendo uma para cada mês.

2- O código alfa-cromático foi utilizado para identificação das etapas da pré-produção até a desprodução em relação à linha do tempo.

3- As setas se distribuem acima e abaixo da linha do tempo equilibram visualmente as informações.

4- Duas barras horizontais no topo e na base do gráfico contém os textos de identificação e servem como uma espécie de fechamento ou moldura para o gráfico. 
Machado, M. A., Formiga, E. L., \& Reis Filho, P. O. | Aplicação da metodologia Design Science Research na indústria do carnaval: a gestão dos métodos e processos de criação coletiva na fábrica do carnaval sob a

Gráfico 4 - Desenhos e anotações feitas no caderno de campo - do autor

\section{C- Artefato cadeia produtiva}

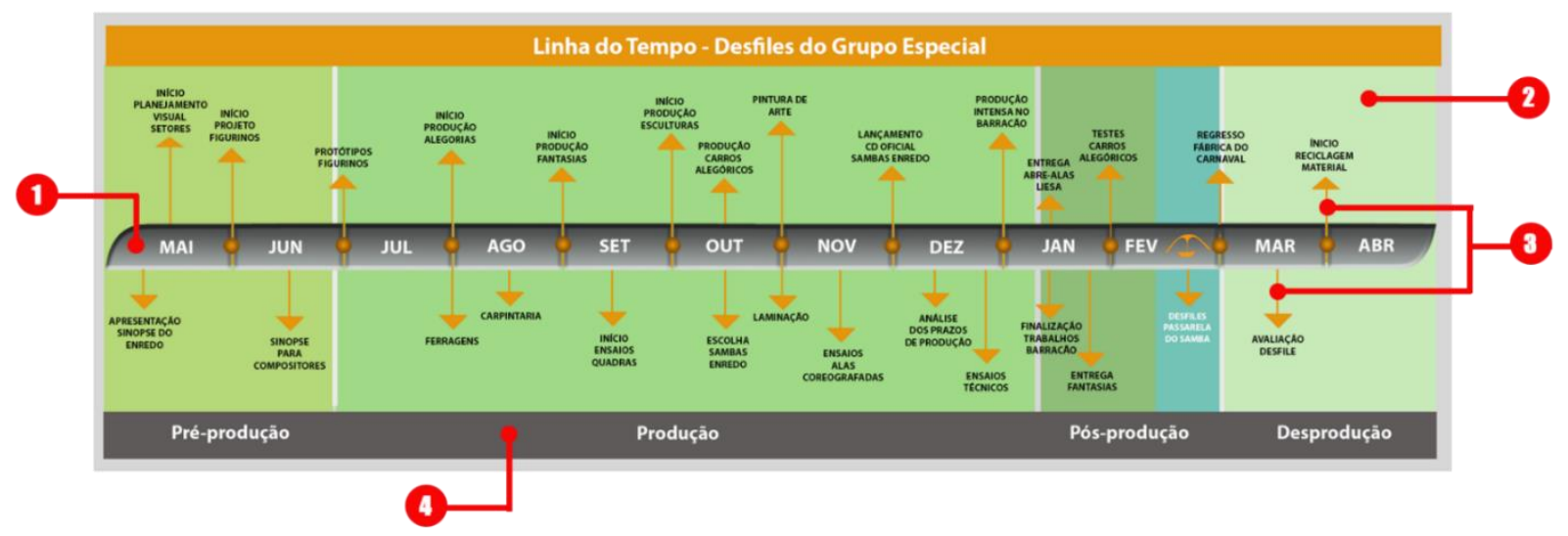

De acordo com Holmes (apud.Steven Hellen,2006), a informação não pode ser exclusiva, mas como o ar, tem que estar em nosso sistema, mesmo que não a percebamos. O modelo escolhido para representação do artefato foi o "Diagrama de Produção" por ser explícito, de fácil compreensão e fornecer uma visão geral da cadeia produtiva na fábrica do carnaval.

1- Boxes com cores de preenchimento foram utilizadas no sentido do fechamento e moldura para as informações.

2- As etapas de Gestão e Criação foram, respectivamente, consideradas parte da área de Pré-produção para efeitos de mapeamento da cadeia.

3- As caixas em diapositivo indicam os destaques na cadeia produtiva.

4- Boxes retangulares com contorno e fontes bastão na cor preta facilitam a visualização e leitura.

5- Linhas e setas indicam as relações de fluxo, sentido e hierarquia entre as informações da cadeia.

6- A utilização de ícones e pictogramas facilitam a identificação dos elos da cadeia produtiva de forma clara e objetiva.

7- Por ser a área com maior número de células de informação, a área de produção segue uma estrutura de relação mista, sendo horizontal entre as sub-áreas e vertical em seu fluxo interno.

8- Considerado o ápice da cadeia produtiva, o ícone passarela do samba possui um design e posicionamento destacados na estrutura.

Obs.: O fluxo das informações é hierárquico e linear verticalmente, objetivando um panorama geral de rápida compreensão do artefato. 
Machado, M. A., Formiga, E. L., \& Reis Filho, P. O. | Aplicação da metodologia Design Science Research na indústria do carnaval: a gestão dos métodos e processos de criação coletiva na fábrica do carnaval sob a ótica do design

Gráfico 5 - Cadeia produtiva elaborado por Marcos Machado (2017)

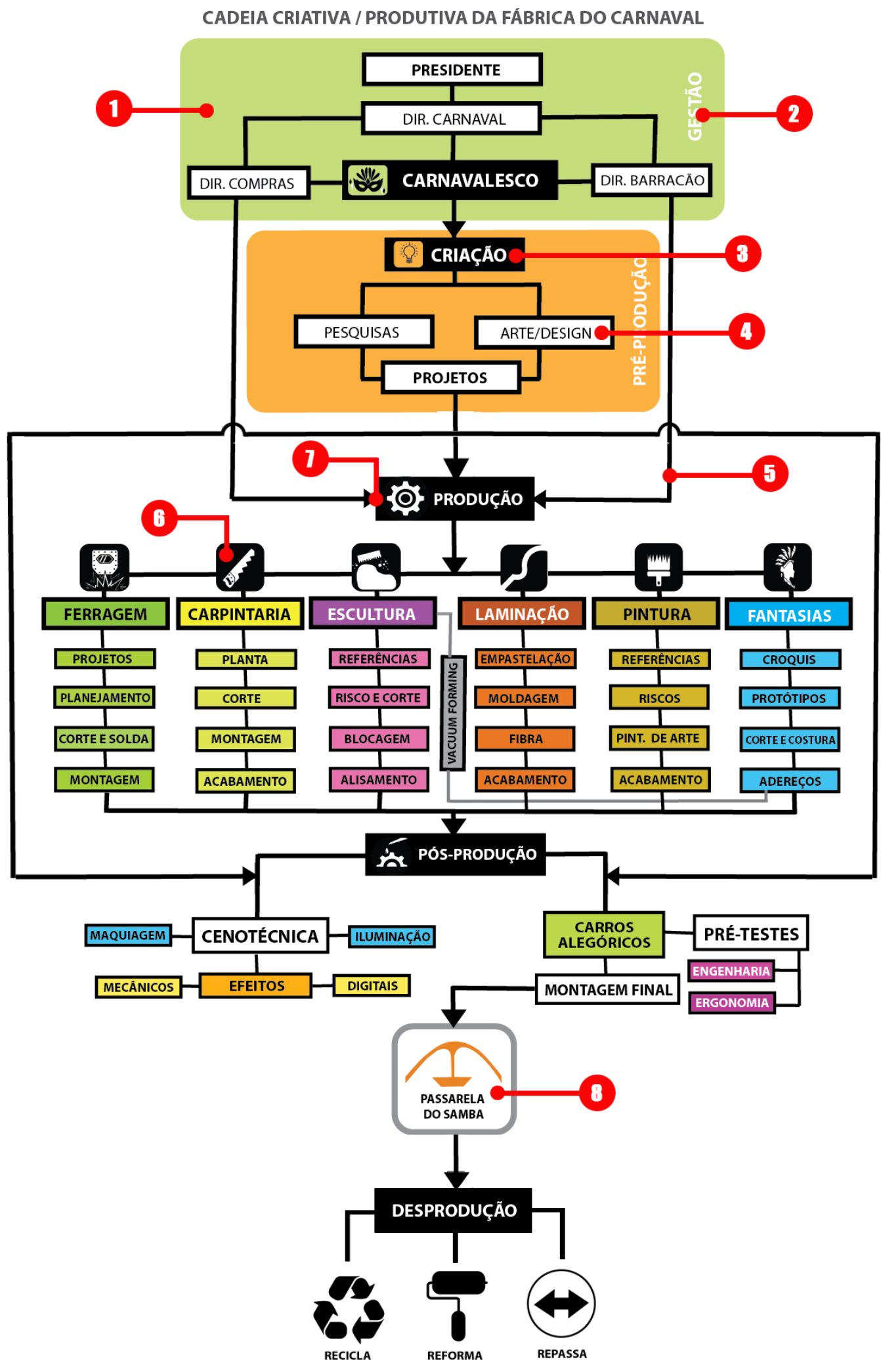


Machado, M. A., Formiga, E. L., \& Reis Filho, P. O. | Aplicação da metodologia Design Science Research na indústria do carnaval: a gestão dos métodos e processos de criação coletiva na fábrica do carnaval sob a

\section{D- Infográfico animado}

Após o mapeamento gráfico da cadeia produtiva na fábrica do carnaval, foi analisada uma maneira de tornar ainda mais explícito o conhecimento envolvido neste processo. A escolha do infográfico animado deu-se a partir de características como a facilidade do desenvolvimento de uma ação complexa, de forma que cada passo incorporado resulte em uma ação subsequente que prende a atenção do expectador de uma forma lúdica e não dispersiva, envolvido em uma narrativa (storytelling) de fácil compreensão.

Como afirma Holmes (2006), o humor é uma ferramenta importante para atrair e reter a atenção, ainda mais se aliada ao desenho, que é capaz de adicionar um estilo pessoal à estética do infográfico.

\section{CIDADEDO SAMBA}

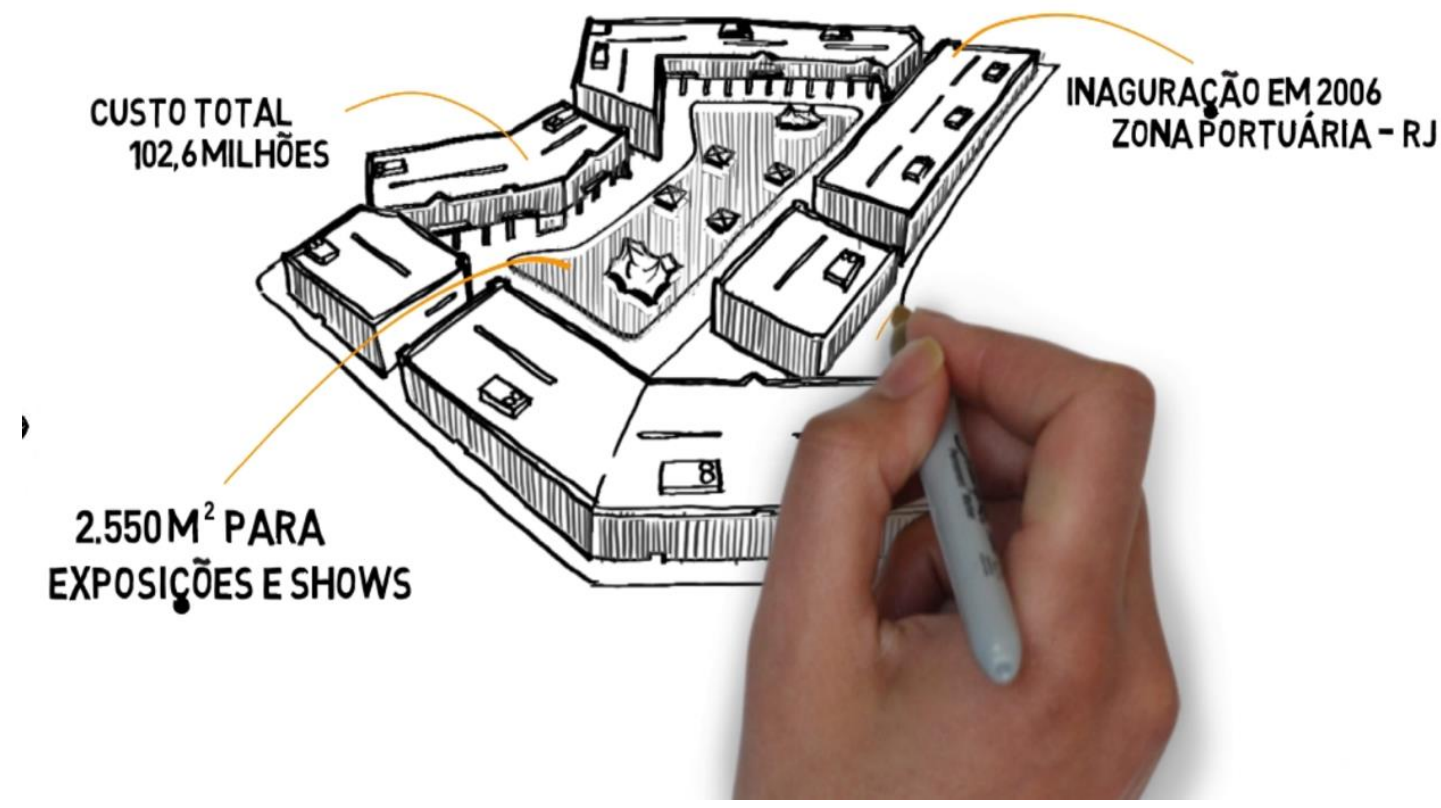

1- O texto, em formato de locução feminina em off, conduz a narrativa (storytelling) de uma maneira suave e objetiva.

2- O áudio da bateria em background agrega ambiência à narrativa.

3- O roteiro segue o fluxo do diagrama de produção através de suas etapas.

4- O sentido da animação dá-se pela interatividade da mão que desenha, posiciona e apaga as informações em um whiteboard.

5- Foram criados desenhos personalizados e lettering para cada etapa da cadeia. $O$ timing da animação foi sincronizado com o ritmo da locução.

6- Os recursos de travelling e zoom foram utilizados com o objetivo de facilitar a narrativa visual do infográfico.

Obs.: Link do Infográfico animado https://www.youtube.com/watch?time continue $=10 \& v=Y k k E i t t c u x 8$ 
Machado, M. A., Formiga, E. L., \& Reis Filho, P. O. | Aplicação da metodologia Design Science Research na indústria do carnaval: a gestão dos métodos e processos de criação coletiva na fábrica do carnaval sob a

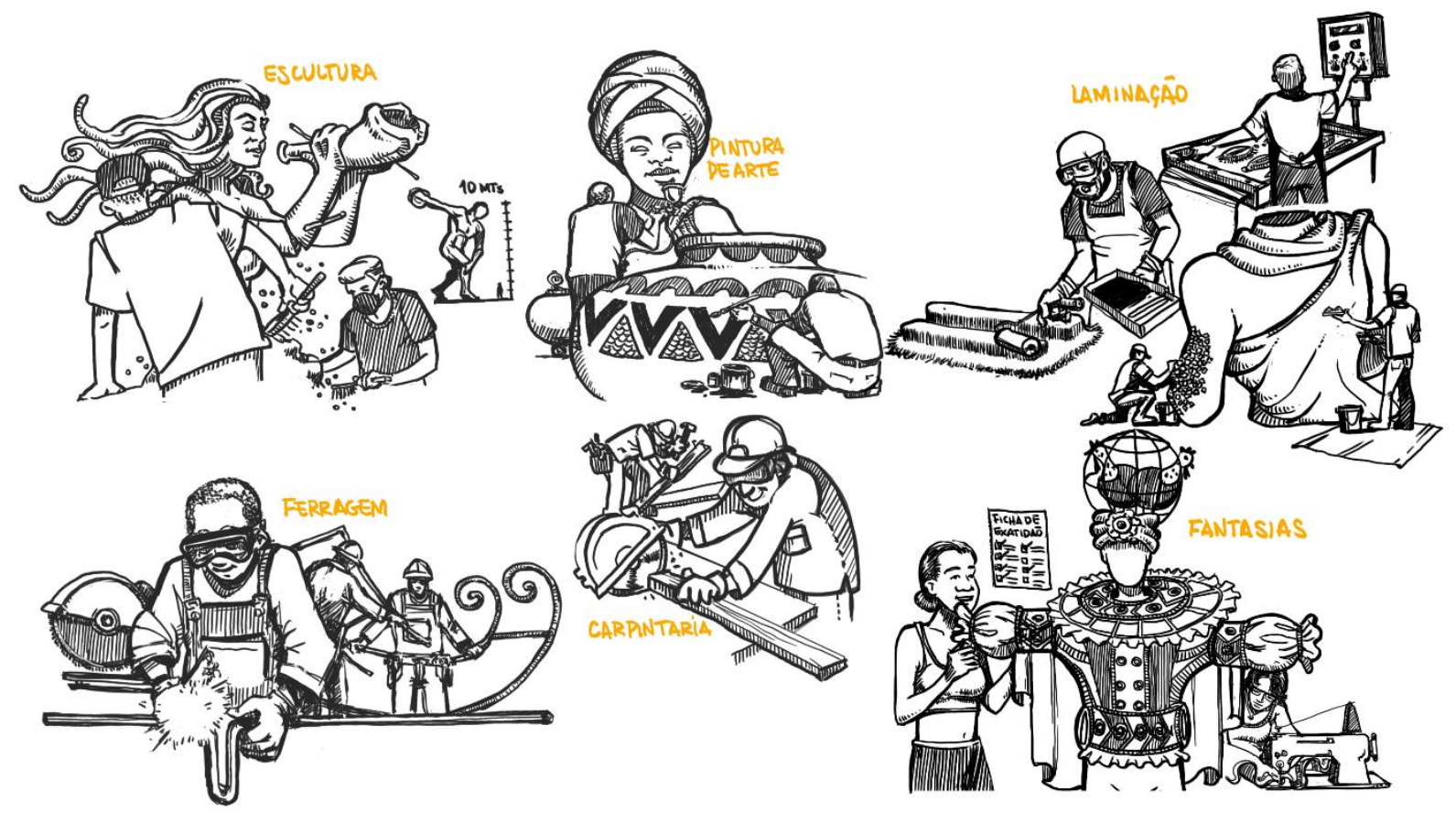

\section{.7. Conclusão}

Ao chegar à fase final da pesquisa, uma consideração pode ser feita: o alcance do objetivo de mapear a cadeia produtiva na Fábrica do Carnaval, identificando os métodos e processos envolvidos. Porém, uma outra consideração também se faz relevante, a constatação da riqueza e do volume do conhecimento gerado em apenas um estudo de caso projeta o que se tem ainda à frente em pesquisas neste campo e confirma a constatação que se o resultado do espetáculo na avenida é deslumbrante, o processo o é ainda mais.

Este presente trabalho buscou caracterizar a estrutura-base nas quais os conteúdos serão visualizados. Assim, por meio da seleção, diferenciação, sequenciamento, hierarquização, conexões e articulações visuais, foi desenvolvido um plano de ação, para efetivar esta capacidade de disseminar informação e de produzir entendimento (Bonsiepe, 1999; Jacobson, 2000). A cada sequência estabelecida durante os processos de pesquisa e interação, a pesquisa buscou reforçar a relação dos achados com os diferentes tipos dimensionais de usuários - dimensão da gestão, dimensão da operação e dimensão comunicacional.

Uma economia criativa baseada no conhecimento e ancorada na cultura e no intangível deve focar mais a fundo as análises das cadeias de produção e sua gestão, identificando e aperfeiçoando os métodos e processos envolvidos. Desta forma, o Design da Informação tende a ser uma ferramenta de crescente importância neste cenário, ampliando os conhecimentos envolvidos através da transformação do saber tácito em um saber explícito.

\section{Referências}

Bonsiepe, G. (1999). Del objeto a la interfase: mutaciones del diseño. Buenos Aires: Ediciones Infinito.

Borja de Mozota, B. (2011). Gestão do Design. Porto Alegre: Bookman.

Dresh, A. (2015). Design Science Research: Método de pesquisa para avanço da ciência e tecnologia. Porto Alegre: Bookman,. 
Machado, M. A., Formiga, E. L., \& Reis Filho, P. O. | Aplicação da metodologia Design Science Research na indústria do carnaval: a gestão dos métodos e processos de criação coletiva na fábrica do carnaval sob a

Ferreira, F. (2004). O Livro de Ouro do Carnaval Brasileiro. Rio de Janeiro: Ediouro.

Fidalgo, A., \& Moura, C. (2014). O design e a fabricação da experiência. In: Fidalgo, António; Canavilhas, João (Orgs.). Comunicação digital: 10 anos de investigação. Covilhã: Livros LabCom, p.11-32.

Freeman, P., \& Hart, D. (2004). A Science of Design for Software. In: Intensive Systems. Communications of the ACM 47, 8, p.19-21.

Hevner, A., March, S., Park, J., \& Ram, S. (2004). Design science in information systems research. MIS Quarterly 28(1), p.75-105.

Horn, R. (2000). Information design: emergence of a new profession. In: JACOBSON, R. (ed.). Information design. Cambridge (MA): The MIT Press.

Horn, R. E. (1998). Visual Language: Global communication for the $21^{\text {st }}$ Century Macro Vu Press.

Jacobson, R. (2000). Information design. Cambridge (MA): The MIT Press.

March, S., \& Smith, G. (1995). Design and Natural Science Research on Information Technology. Decision Support Systems 15, 4, p. 251-266.

Nonaka, I., \& Takeuchi, H. (1997). Criação de conhecimento na empresa. Rio de Janeiro: Campus.

Prestes Filho, L. C. (2009). Cadeia produtiva da economia do carnaval. Rio de Janeiro: EPapers.

Ralph, P., \& Wand, Y. (2009). A proposal for a formal definition of the design concept. K. Lyytinen et al. (Eds.): Design Requirements Workshop, LNBIP 14, p.103-136.

\section{Sobre os autores}

Marcos Aurélio Machado, MSc, ESPM-RJ, Brasil. <marcos.machado@espm.br> Eliana de Lemos Formiga, PhD, ESPM-RJ, Brasil <eformiga@espm.br> Paulo de Oliveira Reis Filho, PhD, ESPM-RJ, Brasil <pauloreis@espm.br> 